\title{
Development of Android Based Online Nurse Test Preparation
}

\author{
Ambar Relawati ${ }^{1}$, Guntur Maulana Zamroni ${ }^{2}$ \\ ${ }^{1}$ School of Nursing - Universitas Muhammadiyah Yogyakarta \\ ${ }^{2}$ Department of Informatics Engineering - Universitas Ahmad Dahlan \\ ${ }^{1}$ ambareumy $\cdot$ ac.id \\ ${ }^{2}$ guntur.zamroni@tif.uad.ac.id
}

\begin{abstract}
The Indonesian Nurses Competency Test (UKNI) is a process to determine whether a person is worthy to become a nurse in Indonesia. In 2018 the UKNI test was carried out by 55,573 total participants with a pass percentage of $\mathbf{4 7 . 1 5 \%}$. This figure is quite low considering the need for nurses in Indonesia which is still quite high. The unpreparedness of participants in facing tests, either readiness in terms of test material or in terms of mentality is one of the causes of the low pass rate of UKNI. Online Nurse Test (ONT) UKNI is expected to be one of the solutions to answer the above problems. ONT UKNI is a mobile application that has been equipped with learning material, try out, and discussion features aimed to help School of Nursing students in facing UKNI test. The development of the ONT UKNI application uses the modified waterfall model and uses the observation approach and literature review in collecting data and materials which will then be used for the development of the ONT UKNI application. ONT UKNI offers new sets of try out questions and discussion feature that may useful for users. Functional tests has been conducted with $100 \%$ results so it can be concluded that the ONT UKNI application is suitable for use.
\end{abstract}

Keywords: Android, Mobile Learning Application, UKNI

\section{INTRODUCTION}

Mobile devices have experienced rapid development along with the development of mobile technology. Mobile devices gradually begin to replace the role of computers with various kinds of applications supported by increasingly sophisticated hardware and software [1]. Figure 1 shows a graph of the number of mobile device application downloads. Mobile applications have increased from year to year. According to reference [2], in 2022 it is predicted that the number of applications downloaded by users is 258.2 billion. Android operating system applications have experienced rapid development and become the choice of application for use by many people because the operating system is open and the large number of applications is available [3].
Android applications can be used for many purposes, such as entertainment, business, education, and so on [4][5]. According to reference [5], applications in the field of education in 2017 increased by 5\% from the previous year. Nursing education is one of the fields that can utilize the Android application as a learning medium in preparation for the Indonesian Nurses Competency Test (UKNI).

UKNI is a process to determine whether a person is worthy to become a nurse in Indonesia as a respond to new regulations by Ministry of Health No. 17962011 regarding healthcare services [6][7]. Reference [8] added that UKNI was aimed for accountability, standard, and ethics for nurses [8]. Figure 2 shows a graph of UKNI pass rates in Indonesia from 2015-2018. From Figure 2 we can see that starting in 2016 the number of participants who passed UKNI tended to be smaller compared to participants who did not pass UKNI. In 2018, there were 3 times of UKNI which were done by 55,573 total participants with a pass percentage of $47.15 \%$ [9]. This figure is quite low considering the need for a nurse profession in Indonesia which is quite high. The Central Bureau of Statistics predicts that the need for nurses in Indonesia is $48,253,428$ nurses with a ratio of 180 nurses per 100,000 population [10]. The need for additional numbers of nurses in Indonesia in 2019 is predicted to be 372,534 nurses [11].

References [12] in their research stated that one of the obstacles faced by UKNI test participants was their unfocused learning. UKNI participants are mostly students who are carrying out professional nursing practices so they do not have enough time to prepare themselves. Other reasons were the participant's ignorance of the UKNI concept especially regarding the UKNI test guidelines and student's Grade Points Average (GPA) better [13][14]. The things above caused the UKNI test participants to have a lack of confidence and confusion in choosing answers which ultimately affected their test results. Students can participate in a try out to help themselves in identifying UKNI's question 
types. UKNI participants who regularly try out will be more prepared and calm in doing the test questions. Thus the test results obtained will be [15].

Reference [16] conducted research on the effectiveness of the use of Android-based learning media for biology subjects in high school students. From the research conducted it can be seen that the use of instructional media has a positive impact. Android-based learning media increases interest and motivation to learn which indirectly increases the effectiveness of learning outcomes. Android-based learning media provides several advantages, such as an attractive design, either in terms of images, colors, or writing. Learning media are also easy to be used independently both at school and outside of school. In another study conducted by reference [17] regarding the use of digital-based learning media, it can be seen that school students are more receptive to learning material in digital form than in written or oral form (lectures). On other research conducted by reference [18] regarding mobile application as a learning media for mathematic subject, it can be seen that students that are using the application feel more well prepared and confident in facing related subject.

This research aims to develop Online Nurse Test (ONT) UKNI applications which is an android-based learning media that is equipped with learning material and try out features. ONT UKNI offers new sets of try out questions and discussion feature. The features that are in ONT UKNI are expected to help nursing students to prepare themselves to face UKNI so that they will get maximum results.

\section{METHOD}

The objective of this research is to develop ONT UKNI application. To achieve this objective, the authors used the Modified Waterfall model in developing software as shown in Figure 3. Modified Waterfall is a model created as a response to traditional Waterfall model that lack of flexibility to be used in the dynamic environment [19][20]. The Modified Waterfall model has the same steps as the traditional Waterfall model, namely: requirements analysis, design, implementation, testing, deployment, and maintenance. In the Modified Waterfall Model, the developer can overlap a stage and can return to the previous stages if a shortage is found.

Figure 3 explains the stages carried out in this research. The authors starts from conducting data collection using observation and literature review. Authors then designing application's flowcharts, use case diagrams, and user interface based on data obtained to provide an overview of business processes and user interfaces of ONT UKNI application. The next step is to implement the design in the form of program code and proceed with the functional testing to see whether the features of the ONT UKNI application work as expected. The next step is the creation of ONT UKNI application APK and database hosting using tools as shown in Table 1 and Table 2. The last stage is the application content update of ONT UKNI.

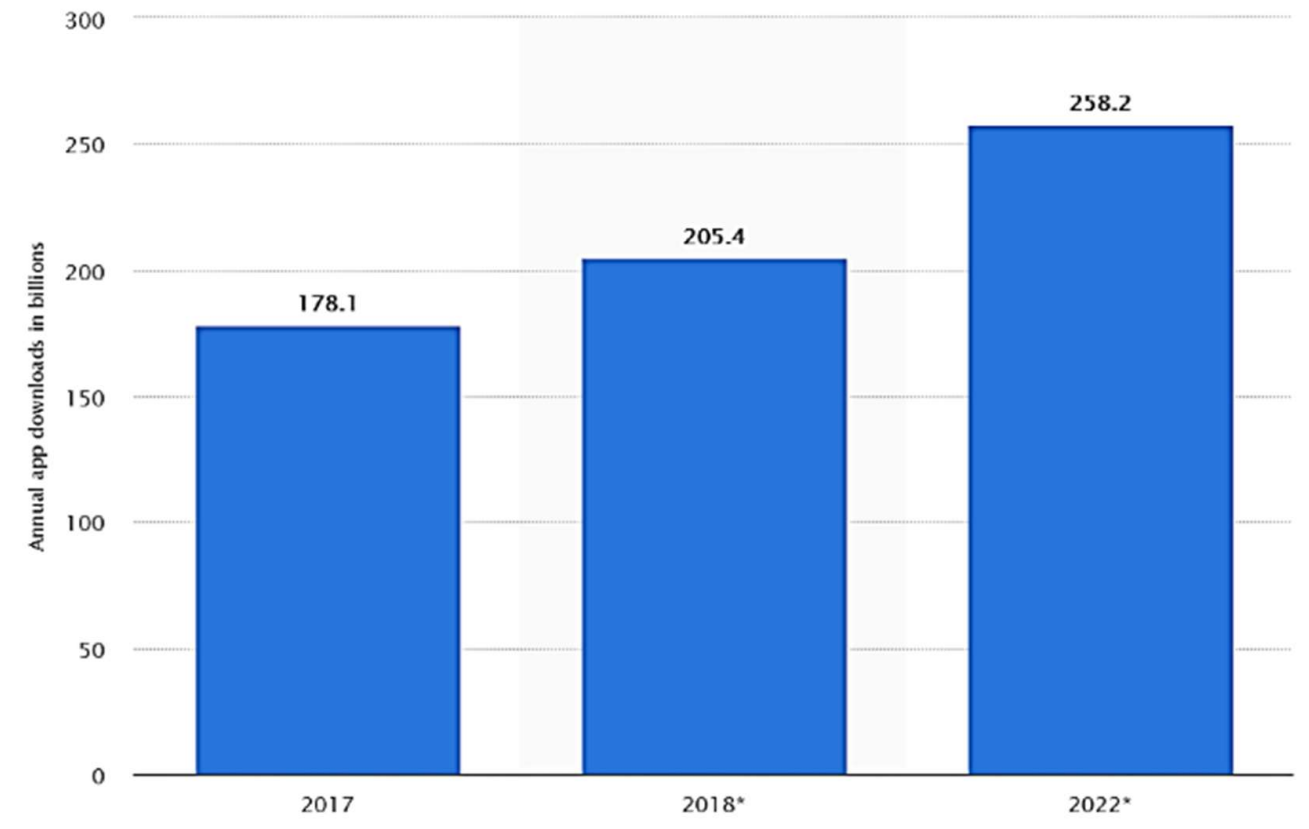

Fig. 1 Number of Downloaded Android Applications 


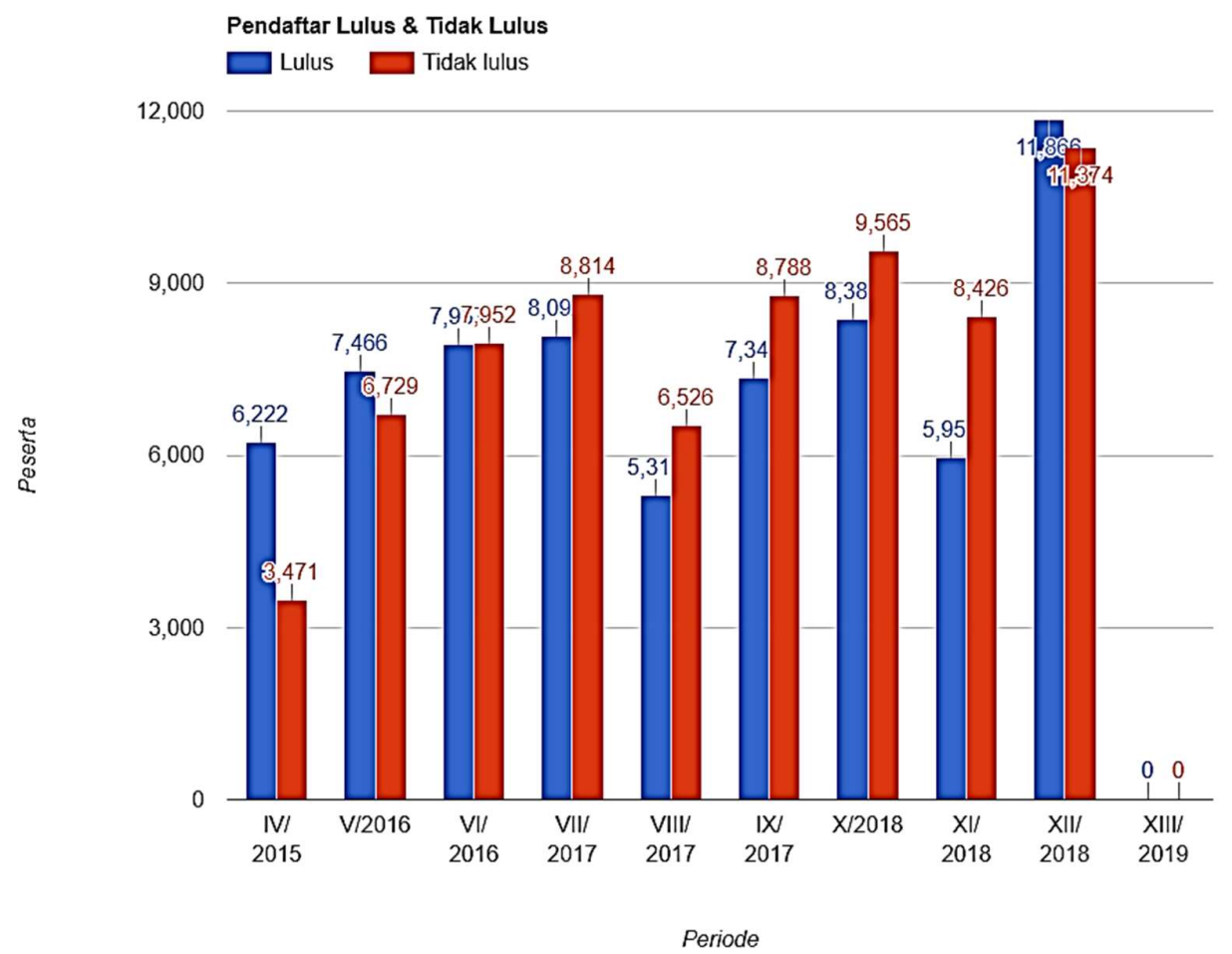

Fig. 2 UKNI Test Statistics From 2015-2019
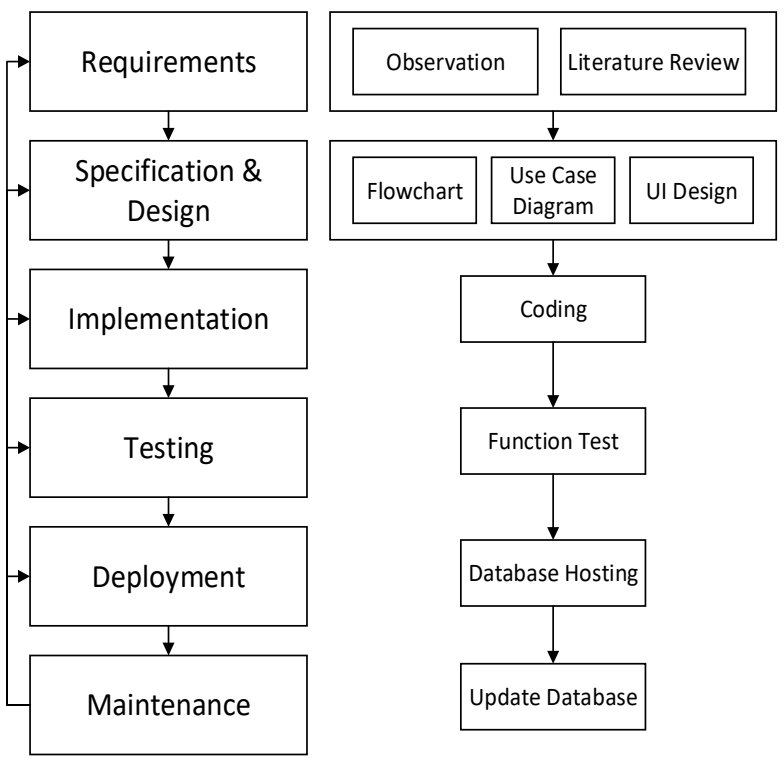

Fig. 3 Modified Waterfall Model
TABLE I

HARDWARE REQUIREMENTS

\begin{tabular}{|c|c|c|}
\hline No. & Hardware & Information \\
\hline 1 & ASUS S14 & Software development tool \\
\hline 2 & $\begin{array}{l}\text { Samsung } \\
\text { Galaxy A3 }\end{array}$ & $\begin{array}{l}\text { Mobile device for software } \\
\text { development and testing }\end{array}$ \\
\hline 3 & USB Cable & Media interface \\
\hline
\end{tabular}

TABEL II

SOFTWARE REQUIREMENTS

\begin{tabular}{|c|c|c|}
\hline No. & Software & Information \\
\hline 1 & XAMPP & $\begin{array}{l}\text { Database development } \\
\text { application }\end{array}$ \\
\hline 2 & $\begin{array}{l}\text { Sublime Text } \\
\text { Editor }\end{array}$ & $\begin{array}{l}\text { Web application development } \\
\text { application }\end{array}$ \\
\hline 3 & Android Studio & $\begin{array}{l}\text { Software development } \\
\text { application }\end{array}$ \\
\hline 4 & Corel Paint X7 & Software development tool \\
\hline 5 & Windows 10 & Operating system for laptop \\
\hline 6 & $\begin{array}{l}\text { Microsoft Word } \\
2013\end{array}$ & Software for documentation \\
\hline 7 & $\begin{array}{l}\text { Android Nougat } \\
7.0\end{array}$ & $\begin{array}{l}\text { Mobile device's operating } \\
\text { system }\end{array}$ \\
\hline 8 & NOX App & Android Emulator \\
\hline
\end{tabular}




\section{RESULTS AND DISCUSSION}

\section{A. Data Collection}

UKNI test uses Multiple Choice Question (MCQ) consisting of 180 questions. The material tested at UKNI is divided into 9 types of scientific material with a number of different questions [21]. Table 3 shows the type and composition of the questions tested on UKNI. Material in the ONT UKNI application is collected and tested involving competent experts in the field of nursing, namely lecturers in the Nursing Study Program at the University of Muhammadiyah Yogyakarta.

\section{B. Business Process}

Figure 4 shows a flowchart diagram of the application to be developed. The users will move from the main menu where 3 menu options will be available: study, try out, and information about the application. In the learning menu, learning materials that have been grouped according to their respective topics will be available. The users will choose a topic and then study material will be displayed. After the users complete a topic, the users can choose to continue learning other topics or return to the main menu.

In the try out menu, the users can do a try out simulation with questions that have been adjusted to follow the UKNI criteria. The test questions that are given will be randomized from 200 questions so that the questions and its order will be different for each user each time they try to conduct try out. The number of questions given is 180 questions with 180 minutes or 3 hours of processing time. The try out result will be displayed after the user completes the try out. If the user has not completed all the questions within the allotted time, the application will automatically stop the test and show the results of the try-out that has been done.

The developed application involves 2 interfaces, namely: Android application with user as actor and web application with admin as an actor as shown in Figure 5. In Figure 5a we can see the activities that can be done by the user, namely: select the learning material, conduct try out, and see about app. Select learning material will give users access to the choice of study material available. The application developed provides 9 topics of learning material that will be tested on UKNI, namely: surgical medical nursing, maternity, children, life, family, gerontic, management, emergency department, and community. After the user chooses one of the topics, the learning material for the selected topic will be displayed and ready to use. If the user selects try out menu, the user will be switched to the question bank selection view where each question bank has 200 questions. After the user completes all 180 questions, the user will be shown a display of test results containing information on the number of questions answered correctly. A discussion menu will appear and can be selected if the user wants to see the discussion of the questions that have been done. The view menu displays information about the application developer, contacts, and references used in the preparation of material and questions. Figure $5 \mathrm{~b}$ shows the activities that can be done by the admin using web application such as CRUD (Create Read Update Delete). By using a web application, the admin can do login activities, edit material, edit questions, and edit settings.

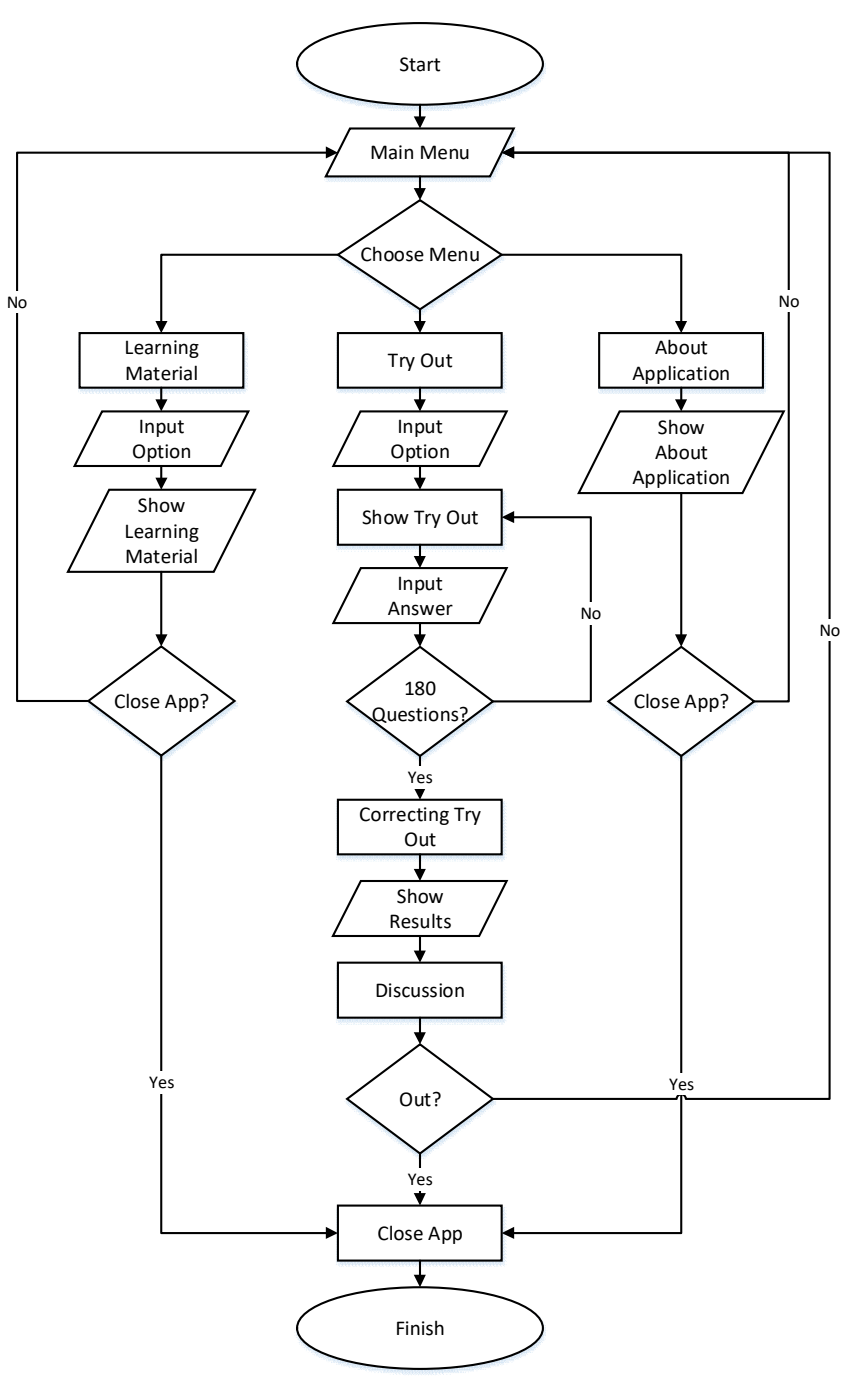

Fig. 4 ONT UKNI Application Flowehart 


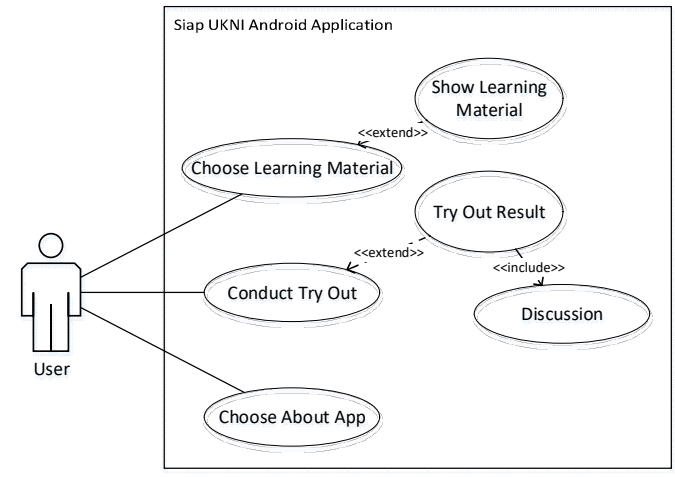

(a) Android App

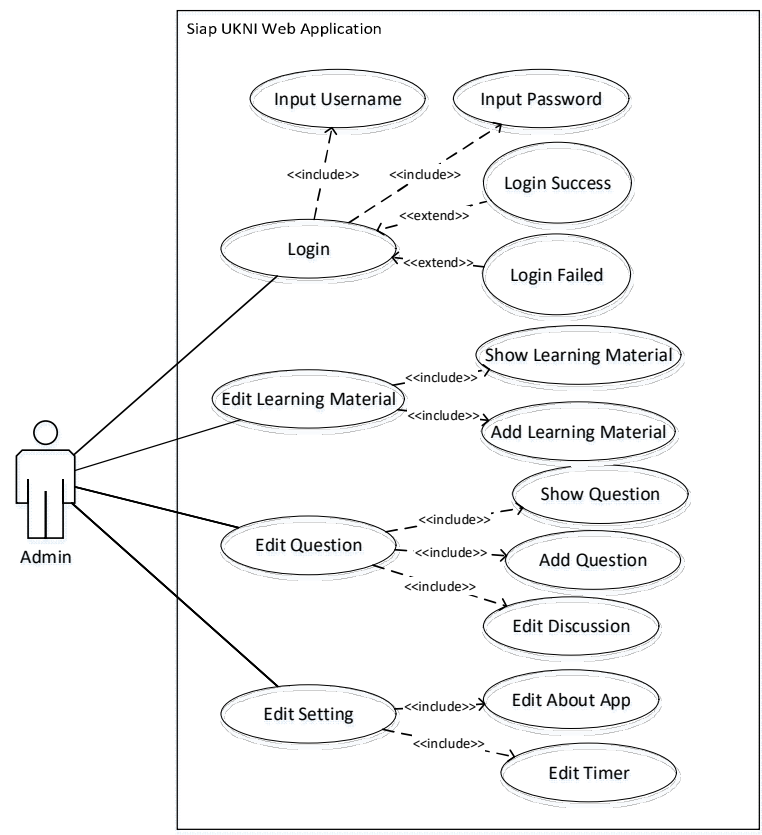

(b) Web App

Fig. 5 Android App Use Case Diagram

TABEL IIII

UKNI TEST MATERIAL COMPOSITIONS

\begin{tabular}{llc}
\hline No. & Topic & Number of Questions (\%) \\
\hline 1 & Medical Surgery & $25-27$ \\
2 & Maternity & $8-14$ \\
3 & Child Care & $8-14$ \\
4 & Mental Health & $8-14$ \\
5 & Family Care & $8-14$ \\
6 & Gerontology & $3-9$ \\
7 & Hospital Management & $3-9$ \\
8 & Emergency Care & $3-9$ \\
9 & Community Care & $3-9$ \\
\hline
\end{tabular}

Login activity is conducted when the admin is about to $\log$ into the web application. Admin will be asked to enter a username and password. If the username and password entered do not match, a notification will appear that the username or password entered is incorrect. If the username and password entered is correct, a notification will appear that the username or password entered is right or correct and the users will be transferred to the main menu. In the main menu display, there are several options such as material menu, question menu, and settings menu to set the display about and test time. Admin can do material editing activities if you want to see existing learning materials. Admin can also add material if the material is deemed necessary to be updated. In editing questions, the admin can see the existing test questions. Admin can also add questions or update the following questions discussion of each question. Admin can set the display contents about by using settings. Options for the duration of the test can also be set in the setting menu.

\section{User Interface Design}

The design of the user interface display as a reference at the writing stage of the program code. At this stage the user interface display of the ONT UKNI application is based on a flowchart and use case diagram with considering touch screen feature, responsive design, updatable and upgradeable, user interface design, and application's features that are suitable for user [22] [23].

Figure 6 shows user interface design of ONT UKNI Android app. The main menu will display the logo and toolbar menu containing the material menu, test menu, and about the developer. If the user selects the material menu, the user will be switched to the material selection menu as shown in Figure 6. From Figure 6 it can be seen that in the user interface design of the material menu there are several topic choices in accordance with the materials at UKNI. Learning material will be displayed according to the topic chosen by the user. On the test menu there are 2 question banks that can be selected by the user. After the user selects one of the question banks, the user will be directed to the display of test questions with a total of 180 questions that have been randomized from the 200 existing questions. All test questions used are of MCQ type with 5 answer choices made in the form 
of radio buttons. The duration of the test will be shown in the form of a countdown timer to assist the user in monitoring the time the test is carried out. After the user selects 1 answer, the user can choose to continue the test to the next question by pressing the right arrow button. The left arrow button is also provided if the user wants to correct answers to the previous questions. About App menu will show the information to be conveyed to the user such as application information, contact lists, and references used for the preparation of learning material and test material for this application.

\section{Code Implementation}

After the design stage, the next stage is to implement the designs in the previous stage into a system or application using Android Studio. The database design is created using XAMPP and the PHP programming language written using Sublime Text Editor to then be uploaded to web hosting. Editing learning material and try out material can be done by using web app. By using online database, admin can doing CRUD operation easier. Figure 7 shows the splash screen of the application and learning material menu which contains topics that are tested on UKNI by using the list-view. If the user selects a topic, the user will be switched to the topic material view then learning material is displayed using scroll-view so as to facilitate interaction between the user and the application.
Figure 8 shows the try out menu. The users can select one of the 2 question banks provided. Each question bank will have a different set of questions so that it will expand the user's perspective on UKNI's questions. The test questions totaled 180 questions that are randomized from 200 questions so that each time the user does the test, the test questions and the order of the test questions will be different. The test has multiple choice question type with 5 answer choices in the form of a radio button. The radio button will facilitate the user in choosing the desired answer. After the user goes for the appropriate answer, the user can press the right arrow button to proceed to the next question. The users can also correct answers to previous questions by pressing the left arrow button. The duration of the test time will be displayed in the form of a countdown timer to assist the user in managing the time to do the test questions. Notification of test results will be displayed when the user completes the test. The users can choose to return to the main menu or see a discussion of the questions being worked on. Figure 9 shows login panel for admin. By using web application interface, admin can do CRUD operation such as add, edit, or delete learning material and test material. Admin can also edit information that want to be shown at about app menu and edit timer for try out feature as shown in Figure 10 and Figure 11.

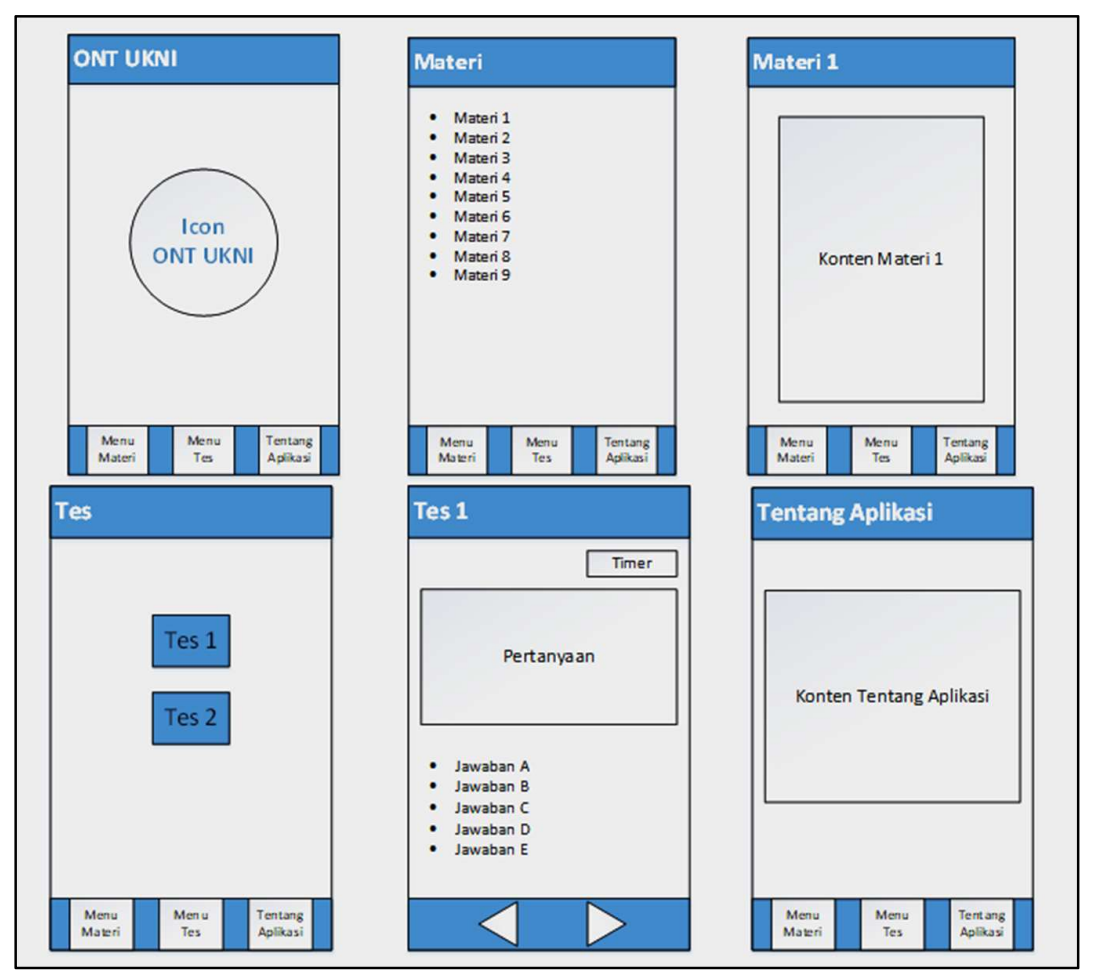

Fig. 6 User Interface Design 


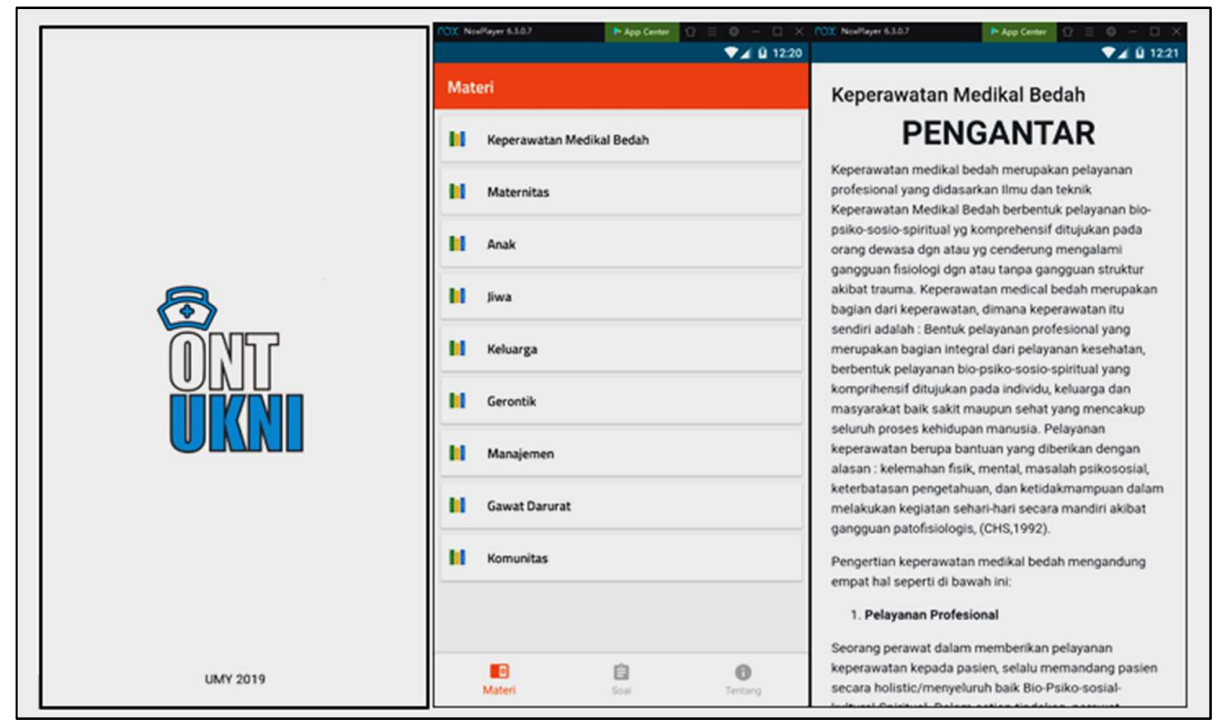

Fig. 7 Learning Material Menu

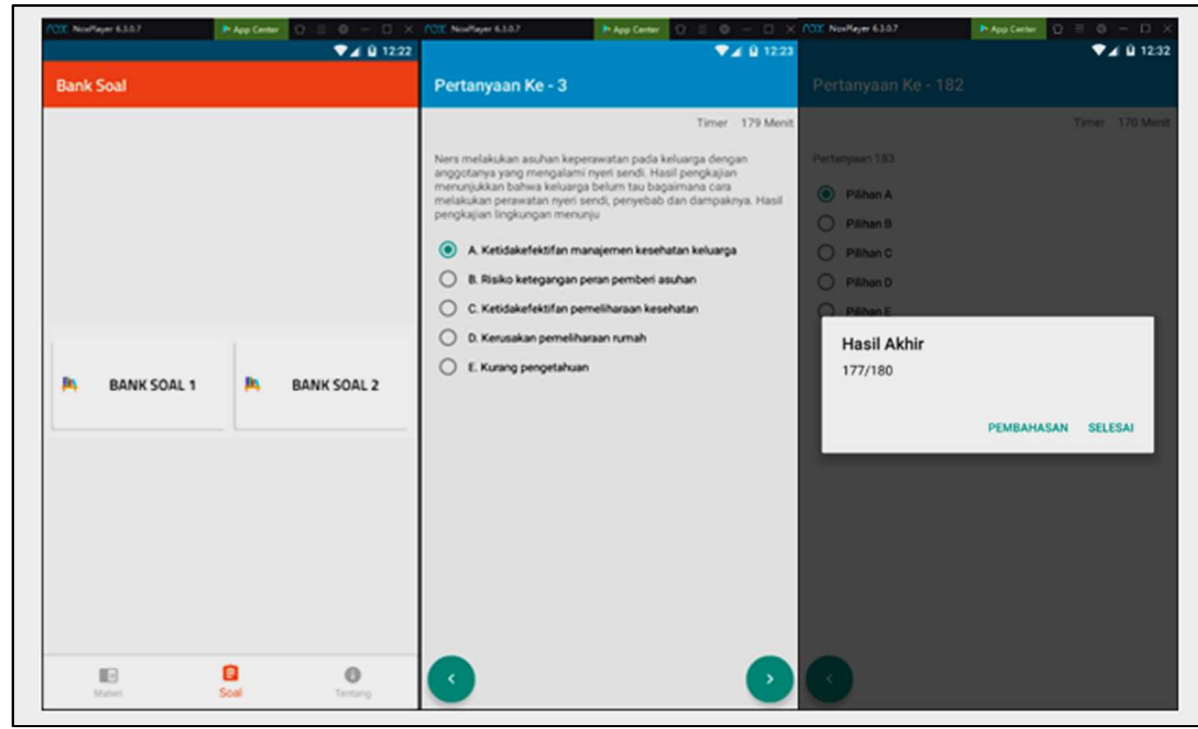

Fig. 8 Try Out Menu

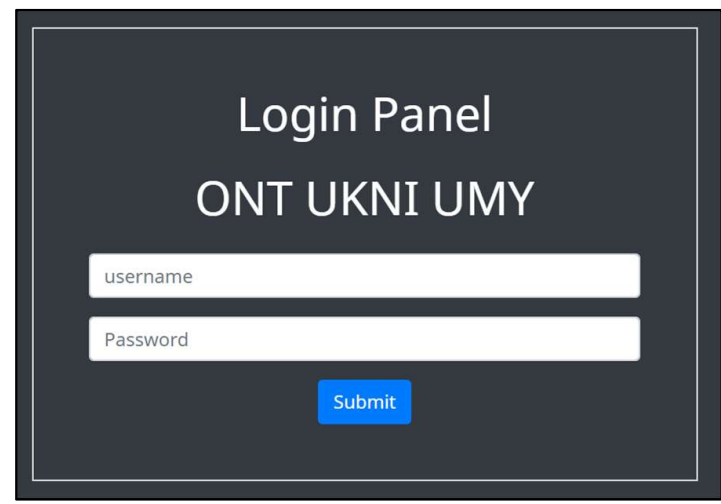

Fig. 9 ONT UKNI Admin Login Panel 


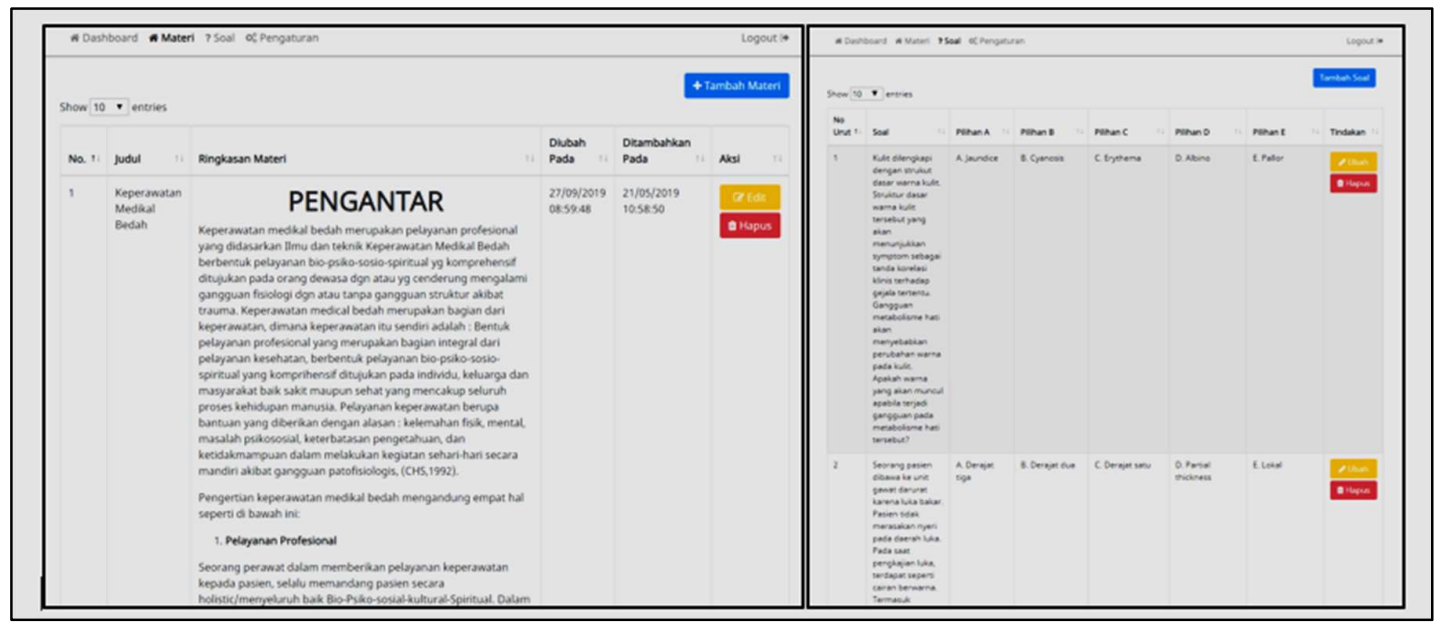

Fig. 10 ONT UKNI Learning Material and Try Out Edit Menu Interface

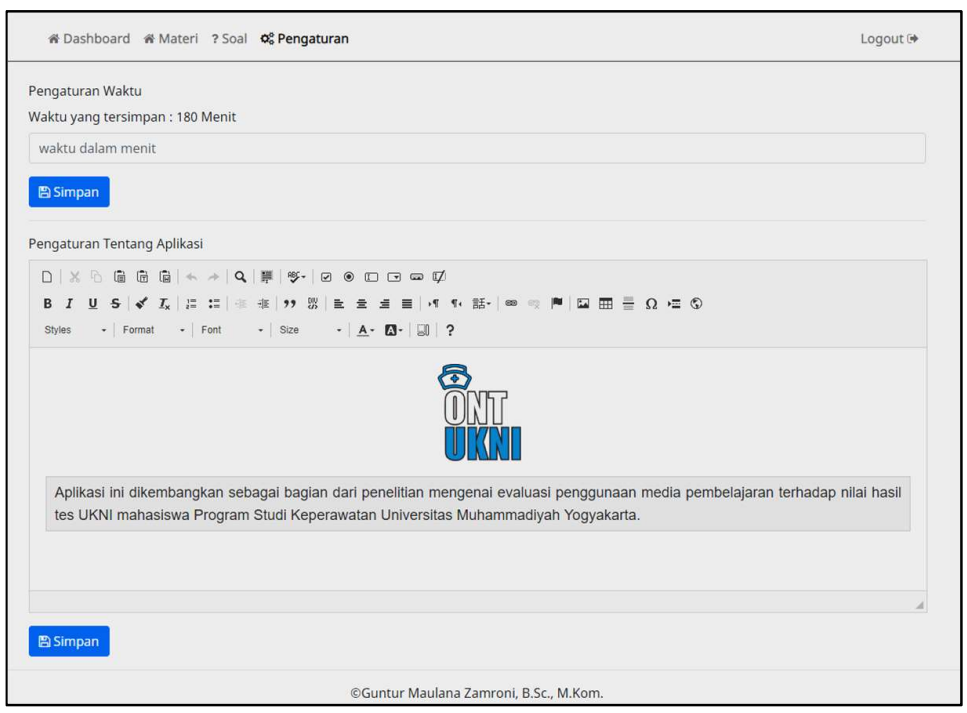

Fig. 11 ONT UKNI Edit Menu Interface

\section{E. Testing}

Testing is carried out in the form of functional tests aimed at testing the features available in the ONT UKNI application. The functional tests begin by creating a table of key components of the developed application and the expected results and results obtained when testing. The results obtained will then be calculated using the percentage of eligibility as shows in Equation 1.

Eligibility Percentages (\%) $=\frac{\text { Test Score }}{\text { Maximum Score }} \times 100 \%$ (1)
Table 4 shows the results of the functional tests that has been conducted. From the results can be seen that all ONT UKNI's features are successfully tested with where each feature met the expected results, whether for mobile app or web app. Based on Equation 1, a percentage of eligibility can be obtained at $100 \%$ as shown below.

$$
\begin{gathered}
\text { Eligibility Percentages (\%) }=\frac{27}{27} \times 100 \% \\
\text { Eligibility Percentages }(\%)=100 \%
\end{gathered}
$$

TABEL IV

UKNI TEST MATERIAL COMPOSITIONS

\begin{tabular}{clc}
\hline \multicolumn{1}{c}{ No. } & \multicolumn{1}{c}{ Components Name } & Test Results \\
\hline Mobile Application & \\
\hline 1 & Learning Material Menu Button & $\sqrt{ }$ \\
2 & Medical Surgery Topic Button & $\sqrt{ }$ \\
3 & Maternity Topic Button & $\sqrt{ }$ \\
\hline
\end{tabular}


TABEL IV (LANJUTAN)

\begin{tabular}{clc}
\hline 4 & Child Care Topic Button & $\sqrt{ }$ \\
5 & Mental Health Topic Button & $\sqrt{ }$ \\
6 & Family Care Topic Button & $\sqrt{ }$ \\
7 & Gerontology Topic Button & $\sqrt{ }$ \\
8 & Hospital Management Topic Button & $\sqrt{ }$ \\
9 & Emergency Care Topic Button & $\sqrt{ }$ \\
10 & Community Care Topic Button & $\sqrt{ }$ \\
11 & Try Out Menu Button & $\sqrt{ }$ \\
12 & Questions Bank 1 Button & $\sqrt{ }$ \\
13 & Questions Bank 2 Button & $\sqrt{ }$ \\
14 & Try Out Answer Radio Button & $\sqrt{ }$ \\
15 & Next Try Out Question Button & $\sqrt{ }$ \\
16 & Previous Try Out Question Button & $\sqrt{ }$ \\
17 & Randomized Try Out Question & $\sqrt{ }$ \\
18 & Answer and Discussion Button & $\sqrt{ }$ \\
19 & Next Answer and Discussion Button & $\sqrt{ }$ \\
20 & Finish Try Out Button & $\sqrt{ }$ \\
21 & About App Button & $\sqrt{ }$ \\
\hline Web Application & $\sqrt{ }$ \\
\hline 22 & Login Menu & $\sqrt{ }$ \\
23 & CRUD Learning Material & $\sqrt{ }$ \\
24 & CRUD Try Out Material & $\sqrt{ }$ \\
25 & CRUD Discussion & \\
26 & Edit About App & Edit Try Out Timer \\
27 & &
\end{tabular}

\section{CONCLUSION}

In this research an Android-based ONT UKNI application is developed with features created to help nursing students and potential UKNI participants prepare themselves for the UKNI. Based on the functional tests conducted, it can be concluded that the ONT UKNI application is work as expected and is suitable for use as a learning media for nursing students in preparing themselves for the UKNI. Further research regarding usability testing and experiment need to be done in the future to see how user friendly and how effective ONT UKNI application is in helping students preparing UKNI exam.

\section{REFERENCES}

[1] M. Elgan, "With Smartphones Like This, Why Do We Need Laptops?," 2017. [Online]. Available: https://www.computerworld.com/article/3241233/smart phones/with-smartphones-like-these-why-do-we-needlaptops.html. [Accessed: 24-Jan-2019].

[2] statista.com, "Number of Mobile App Downloads Worldwide in 2017, 2018 and 2022 (in billions)," 2019. [Online]. Available: https://www.statista.com/statistics/271644/worldwidefree-and-paid-mobile-app-store-downloads/. [Accessed: 24-Jan-2019].
[3] A. Dogtiev, "App Downlaod and Usage Statistics (2018)," 2019. [Online]. Available: http://www.businessofapps.com/data/app-statistics/. [Accessed: 24-Jan-2019].

[4] A. Manan, V. Wiley, and T. Lucas, "Application Design for Food and Beverage Online Delivery System Based of Android Framework," JUITA J. Inform., vol. 7, no. 2, p. 101, 2019.

[5] E. Enge, "Mobile vs Desktop Usage in 2018: Mobile Takes The Lead," 2018. [Online]. Available: https://www.stonetemple.com/mobile-vs-desktop-usagestudy/. [Accessed: 24-Jan-2019].

[6] Medianers, "Tentang Uji Kompetensi Perawat," 2017. [Online].

Available: https://medianers.blogspot.com/2017/05/tentang-ujikompetensi-perawat.html. [Accessed: 21-Jan-2019].

[7] R. A. Sari, "Uji Kompetensi Perawat." Universitas Diponegoro, Semarang, 2014.

[8] M. Ilyas, "Standarisasi Uji Kompetensi Menuju System Pelayanan Kesehatan Yang Aman Untuk Semua," Makassar, 2012.

[9] RISTEKDIKTI, “Data Statistik UKNI," 2019. [Online]. Available: http://ukners.ristekdikti.go.id/statistik. [Accessed: 21-Jan-2019].

[10] L. F. Manalu, "Menyikapi Krisis Kekurangan Perawat," SINDOnews, 2017. [Online]. Available: https://nasional.sindonews.com/read/1210047/18/menyi kapi-krisis-kekurangan-perawat-1496348683. [Accessed: 
23-Jan-2018].

[11] Global Health Workforce Alliance, "Rencana Pengembangan Tenaga Kesehatan Tahun 2011-2025," 2011.

[12] S. Kholifah and W. Kusumawati, "Hambatan Lulusan Ners Dalam Menghadapi Uji Kompetensi Ners Indonesia," Indones. J. Heal. Sci., vol. 7, no. 1, pp. 4047, 2016.

[13] A. Abdillah, "Analisis Faktor-Faktor Yang Mempengaruhi Kelulusan Uji Kompetensi Ners Indonesia," J. Penelit. Adm. Publik, vol. 2, no. 2, pp. 373-380, 2016.

[14] L. Hakim and L. S. Pusporini, "Analisis Faktor Yang Mempengaruhi Capaian Kelulusan Uji Kompetensi Ners Mahasiswa Program Profesi Ners," Cakrawala Pendidik., vol. 37, no. 2, 2018.

[15] A. Hartina, T. Tahir, N. Nurdin, and M. Djafar, "Faktor Yang Berhubungan Dengan Kelulusan Uji Kompetensi Ners Indonesia (Ukni) Di Regional Sulawesi," J. Persat. Perawat Nas. Indones., vol. 2, no. 2, p. 65, 2018.

[16] S. Muyaroah and M. Fajartia, "Pengembangan Media Pembelajaran Berbasis Android dengan menggunakan Aplikasi Adobe Flash CS 6 pada Mata Pelajaran Biologi Abstrak," vol. 6, no. 2301, pp. 79-83, 2017.

[17] A. Teodorescu, "Mobile learning and its impact on business English learning," Procedia - Soc. Behav. Sci., vol. 180, no. November 2014, pp. 1535-1540, 2015.

[18] Ansari S. Ahmar and Abdul Rahman, "Development of teaching material using an Android," Glob. J. Eng. Educ., vol. 19, no. 1, pp. 72-76, 2017.

[19] L. Rayo, “Modified Waterfall Model,” Prezi Inc., 2015. [Online]. Available: https://prezi.com/ne8i4bsjeyf/modified-waterfall-model/.

[20] I. A. Bahrudin, "a Comparative Study of User Acceptance Testing Between Modified Waterfall Model and Extreme Programming in Small-Scale Project Ida Aryanie Bahrudin Status Confirmation for Master ' S Dissertation," 2016.

[21] RISTEKDIKTI, "Blueprint Uji Kompetensi Program Studi DIII Keperawatan dan Profesi Ners,” 2017.

[22] I. J. K. G. Prabowo, A. Setiawan, and S. T. Prakoso, "Pengembangan Sistem Mobile Journal Berbasis Android Untuk Referensi Belajar Mahasiswa Di Lingkungan Fakultas Ekonomi UNY," in Program Kreativitas Mahasiswa - Karsa Cipta 2013, 2013, pp. 13.

[23] K. Baktha, "Mobile Application Development: All the Steps and Guidelines for Successful Creation of Mobile App : Case Study," vol. 6, no. 9, pp. 15-20, 2017. 